\title{
Perilaku Prososial Siswa dan Implikasi Program dalam Bimbingan Pribadi Sosial
}

\author{
Kharisma Berlianti Balengka $^{1}$, Deasy Yunika Khairun ${ }^{2}$, Rahmawati ${ }^{3}$ \\ ${ }^{1}$ Fakultas Keguruan dan Ilmu Pendidikan \\ Universitas Sultan Ageng Tirtayasa \\ ${ }^{1}$ rismaberlian@gmail.com
}

\begin{abstract}
The purpose of this study was to determine the level of prosocial behavior in 11 IPS students of SMA Negeri 1 Cilegon City. The method used in this research is descriptive quantitative research. Sampling of this research used Probability Sampling technique with the proportional random sampling method using a questionnaire. Participants in the study were students of class XI IPS 1-4, 142 students. This study aims to assess the prosocial aspects of students which consist of 5 aspects, namely helping, sharing, giving, cooperating and being honest. The results showed that the description of students' prosocial behavior was divided into three categories, high with a percentage of $20 \%$, medium category with a percentage of $63 \%$, and low category with a percentage of $17 \%$. In terms of aspects, the lowest results in this study were in the aspect of "helping" with a value of 59\% and the highest was in the aspect of "sharing" with a value of $73 \%$. Based on the results of the study, it can be concluded that there is a low potential for moderate and low prosocial behavior so that efforts are needed to improve prosocial behavior for students. These efforts are implicated in the making of Personal-Social Guidance and Counseling programs to improve students' prosocial behavior.
\end{abstract}

Key words: prosocial, teenage, guidance, counseling, student.

\begin{abstract}
Abstrak
Tujuan penelitian ini adalah untuk mengetahui tingkat perilaku prososial pada siswa 11 IPS SMA Negeri 1 Kota Cilegon. Metode yang digunakan dalam penelitian ini adalah penelitian deskriptif kuantitatif. Pengambilan sampel dilakukan dengan teknik Probability Sampling dengan metode Propotional Random Sampling. Partisipan dalam penelitian yaitu siswa kelas XI IPS 1-4 yang berjumlah 142 siswa. Penelitian ini bertujuan untuk menilai aspek-aspek prososial siswa yang terdiri atas 5 aspek yaitu menolong, berbagi, berderma, kerjasama dan jujur. Hasil penelitian terbagi menjadi tiga kategori, yaitu tinggi dengan presentase $20 \%$, kategori sedang dengan presentase 63\%, dan kategori rendah dengan presentase $17 \%$. Dari segi aspek, Hasil terendah pada penelitian ini berada pada aspek membantu dengan nilai sebesar 59\% dan tertinggi pada aspek berbagi dengan
\end{abstract}


nilai sebesar $73 \%$. Berdasarkan hasil penelitian dapat disimpulkan adanya potensi rendahnya perilaku prososial sedang dan rendah sehingga diperlukan upaya untuk meningkatkan perilaku prososial bagi siswa. Upaya tersebut diimplikasikan dalam pembuatan program Bimbingan dan Konseling Pribadi-Sosial untuk meningkatkan perilaku prososial siswa.

Kata kunci: Prososial, Remaja, Bimbingan, Konseling, Siswa.

\section{Pendahuluan}

Penyelenggaraan bimbingan dan konseling dalam lingkup SMA berlandaskan pada undang-undang sistem pendidikan nasional nomor 20 tahun 2003 pasal 1 butir 1 yang berbunyi: "pendidikan adalah usaha sadar dan terencana untuk mewujudkan suasana belajar dan proses pembelajaran agar peserta didik secara aktif mengembangkan potensi dirinya untuk memiliki kekuata spiritual keagamaan, pengendalian diri, kepribadian, kecerdasan, akhlak mulia, serta keterampilan yang diperlukan dirinya, masyarakat, bangsa dan negara". Tujuan penyelenggaraan Bimbingan dan Konseling di SMA yaitu untuk membantu siswa dalam mengatasi permasalahan yang terjadi dalam kehidupanya saat ini yang berkaitan dengan sikap dan perilaku individu maupun sosialnya. Penerapan Bimbingan dan Konseling ranah SMA memerlukan perhatian khusus karena seperti yang sudah kita ketahui bahwa anak SMA masuk dalam kategori masa adolescent yaitu pada usia 15-17 tahun atau 16-19 tahun yaitu suatu periode yang tidak mudah (perubahan dari masa anak ke masa remaja) diman mereka banyak menghadapi kesulitan dan banyak gejolak yang menandai masa perkembangan remaja, misalnya masalah yang sifatnya psikis (tingkah laku delinqen), masalah-masalah situasional, unpredictable, masalah hubungan muda-mudi, masalah perkembangan seksual, masalah sosial ekonomi,masalah masa depan dan lain-lain (Solihah, 2013).

Salah satu urgensi pendidikan adalah untuk membangun dan menanamkan karakter sikap yang positif dari inidividu atau umumnya disebut perilaku prososial yang mana penangananya masuk dalam ranah Bimbingan dan Konseling. Pengertian Perilaku prososial menurut William (Trifiana, 2015) adalah serangkaian perilaku yang dilakukan seseorang dengan tujuan merubah kehidupan orang lain dari kondisi yang dianggap kurang atau tidak baik ke arah yang lebih baik. Perilaku prososial merupakan perilaku yang memang umumnya dilakukan oleh individu di sosial atau dengan sosialnya. Perilaku 
prososial khususnya bagi remaja memiliki 5 aspek menurut Mussen (Sabiq, 2012) yaitu : berbagi, menolong, berderma, kerjasama dan jujur. Namun, pada kenyataanya saat ini banyak ditemukan kasus kemunduran dari perilaku prososial di masyarakat khususnya di kehidupan remaja. Pesatnya kemajuan di berbagai bidang kehidupan manusia, seiring dengan proses globalisasi telah menimbulkan dampak negatif. Akibatnya, menurut Tarmudji (Prasetyo, 2017) bukanlah hal yang aneh bila nilai-nilai pengabdian, kesetiakawanan, dan tolong menolong mengalami penurunan.

Berdasarkan hasil pengamatan peneliti selama menjalani Praktik Pengalaman Lapangan (PPL-BK) di SMA Negeri 1 Cilegon ditemukan masih kurangnya sikap-perilaku prososial pada perilaku siswa-siswi di dalam keseharian pembelajaran, seperti kurangnya sikap kerja sama dan tolong menolong antarsiswa. Hasil sosiogram di beberapa kelas menunjukkan adanya siswa-siswi yang dikucilkan dari kegiatan berkelompok, tidak ditolong saat mengerjakan tugas dan siswa lain cenderung kurang bekerjasama. Selain itu, di beberapa kelas ditemukan sikap acuh tak acuh yang cukup tinggi yang ditunjukan siswa kepada peneliti yang menjadi mahasiswa praktik pada saat PPL-BK berlangsung contohnya siswa sibuk sendiri dengan kegiatan yang dilakukanya sehingga terlihat seperti tidak menghargai kehadiran peneliti. Hal ini juga didukung oleh permasalahanpermasalahan pribadi dan sosial yang cukup tinggi terjadi di kelas XI IPS yang terungkap pada angket Daftar Cek Masalah (DCM). Peneliti juga menjadikan DCM sebagai asesmen awal untuk program peneliti saat PPL-BK yang pada akhirnya membuat peneliti memilih kelas XI IPS untuk diteliti dibandingkan kelas XI IPA karena hasil DCM kelas XI IPA cenderung menunjukan permasalahan yang terkait dengan bidang belajar atau akademik bukan dengan bidang pribadi dan sosial.

Penelitian Saleem, Barlett, Anderson, dan Hawkins (2016) menyatakan bahwa remaja yang menunjukkan perilaku prososial yang rendah cenderung menunjukkan kecenderungan tanggung jawab sosial rendah, kecenderungan menyakiti orang lain, dan perilaku agresi lainnya yang tinggi terdapat kemungkinan bahwa remaja-remaja yang tidak mampu menunjukkan perilaku prososial dan disertai kemunculan perilaku-perilaku maladaptif menjadi remaja yang tidak diinginkan bahkan ditolak oleh kelompok sebayanya (Rahajeng dan Wigati, 2018). Hal ini diperkuat pula oleh studi penelitian sebelumnya oleh Hamidah (Isnandar, 
2010) yang menemukan ditujuh daerah di Jawa Timur menunjukkan adanya indikasi penurunan kepedulian sosial dan kepekaan terhadap orang lain banyak terjadi pada remaja yang nampak lebih mementingkan diri sendiri dan keberhasilanya tanpa mempertimbangkan keadaan orang lain di sekitarnya. Hal ini menyebabkan remaja menjadi semakin individualis dan perilaku prososial yang dimiliki semakin pudar. Sedangkan pada penelitian lainya ditemukan bahwa ada hubungan positif yang sangat signifikan antara penalaran moral dengan perilaku prososial pada remaja.

Beberapa faktor dapat mempengaruhi baik tidaknya perilaku prososial siswa. Penelitian sebelumnya oleh Herdiyanto (2016) menunjukan dari segi kesehatan terdapat hubungan signifikan dan positif antara perilaku prososial dengan psychological well-being yang berarti semakin tinggi frekuensi seorang remaja melakukan perilaku prososial maka tinggi pula psychological well-being (kesehatan mental) yang dimiliki remaja tersebut. Faktor yang berasal dari hubungan anak dengan Orang tua juga bisa menjadi salah satu pemicu baik tidaknya sikap anak di lingkungan sosialnya, hal ini didukung oleh penelitian Elistantia, Yusmansyah, dan Utaminingsih (2018) yang menunjukan perilaku prososial pada diri remaja juga dapat dipengaruhi oleh orang tua baik itu dari segi pola asuh atau dari hubungan interpersonal diri remaja dengan orang tuanya. semakin besar dukungan sosial orang tua maka akan semakin tinggi pula kemauan siswa untuk berperilaku prososial. Partini dan Lestari (2015) yang memaparkan dari segi moral adanya hubungan positif yang sangat signifikan antara penalaran moral dengan perilaku prososial pada remaja. Semakin positif perilaku prososial pada diri remaja, semakin baik juga perilaku yang diperlihatkan di lingkungan sosial.

Tujuan dan manfaat dari penelitian ini adalah untuk mengetahui bagaimana tingkat perilaku prososial siswa yang menjadi subjek penelitian sehingga dapat dibuat program yang dapat diaplikasikan untuk mengatasi permasalahan perilaku prososial yang terjadi pada siswa.

\section{Metode Penelitian}


Pengambilan data menggunakan pendekatan kuantitatif deskriptif. Kriteria populasi penelitian adalah siswa kelas XI IPS 1-4, berusia 16-18 tahun yang bersekolah di SMA Negeri 1 Cilegon sebanyak 142 responden. Teknik Sampling yang digunakan yaitu Probability Sampling dengan metode Propotional Random Sampling dan setelah dilakukan sampling terambil data dari 105 responden terpilih. Teknik pengambilan data menggunakan angket google form yang berisi 50 buah pernyataan. Opsi jawaban mengacu pada skala likert (Rensis Likert) yaitu: Sangat tidak setuju,Tidak setuju,Setuju dan Sangat setuju. Peneliti menghilangkan opsi kurang setuju untuk menghindari jawaban yang nilainya "bias". Angket yang digunakan memiliki nilai validitas 0.30 dan reabilitas Alpha Cronbach 0,889. Data dianalisis melalui aplikasi Microsoft excel yang kemudian diolah sedemikian rupa sehingga dapat menjadi kumpulan data yang dapat diinterpretasikan.

\section{Hasil dan Pembahasan}

\section{Perilaku prososial siswa secara umum}

Berdasarkan hasil penelitian yang dilakukan, dapat diketahui bahwa tingkat penyesuaian diri peserta didik kelas XI IPS SMA Negeri 1 Cilegon digolongkan pada tiga kategori yaitu rendah, sedang dan tinggi. Jumlah responden terbanyak berada pada kategori sedang sebanyak 66 responden dengan besaran presentase $63 \%$. Sementara, peserta didik berada pada kategori rendah sebesar $17 \%$ dan peserta didik yang termasuk dalam kategori tinggi sebesar 20\%. Hal ini sebanding dengan penelitian yang dilakukan oleh Tandi (2019) menggunakan kategori rentang usia remaja yang sebanding dengan kriteria populasi milik penulis yang menunjukkan bahwa sebanyak 68 siswa (32\%) memiliki perilaku prososial yang sangat tinggi, sebanyak 130 siswa (60\%) memiliki perilaku prososial yang tinggi, sebanyak 18 siswa ( $8 \%$ ) memiliki perilaku prososial yang sedang, tidak ada siswa yang memiliki perilaku prososial yang rendah dan sangat rendah. Hasil penelitian ternyata berbanding terbalik dengan fenomena awal karena perilaku prososial siswa kelas IX IPS SMA Negeri 1 Cilegon tidak dalam kategori rendah dan bermasalah, melainkan berada dalam kategori sedang. Namun tetap perlu adanya upaya untuk meningkatkan perilaku prososial pada peserta didik kelas XI IPS SMA Negeri 1 Cilegon. 
Individu dalam masa remaja yang masuk dalam lingkungan sosial seperti lingkungan sekolah biasanya sudah mengenal norma seperti apa yang berlaku di lingkungan tersebut, individu juga sudah mampu memilah-milih mana perilaku yang baik dan sesuai dalam tatanan masyarakat di suatu lingkup sosial dan mana perilaku yang kurang maupun tidak sesuai. Pendapat peneliti didukung oleh pendapat Latifah (Amseke \& Panis, 2020) yang menyatakan bahwa remaja adalah suatu masa transisi yang ditandai dengan perkembangan psikologis dan sosial, maka sehubungan dengan hal itu secara umum siswa sudah mengetahui perilakuperilaku yang baik dan positif, remaja juga sudah bisa membedakan tindakan yang baik dan buruk.

Menurut Hurlock (Tandi, 2019) remaja awal memiliki ciri-ciri yakni salah satunya mengalami perubahan perilaku dan sikap yang berlangsung sangat pesat. Hal ini sejalan dengan pendapat peneliti yang merasa bahwa dalam rentang usia responden yang berkisar antara 15-18 tahun tergolong remaja awal jadi wajar jika siswa sebagai reponden yang saat isi berada di usia remaja sedang mengalami banyak perubahan perilaku dan perubahan yang terjadi berlangsung cepat.

Peterson (Tandi, 2019) yang menyatakan bahwa semakin bertambahnya usia maka akan membuat individu dapat menjadi lebih empati, dapat memahami nilai, dan menemukan makna dari setiap perilaku prososial yang ditunjukan. Hal ini sejalan dengan pendapat meneliti yaitu sikap-perilaku prososial lebih banyak muncul dan berubah-ubah pada usia remaja dibandingkan pada usia anak karena semakin bertambahnya usia dapat membuat individu lebih berfikir kritis dan bertindak logis.

Hasil penelitian menunjukan meskipun secara keseluruhan perilaku prososial siswa XI IPS berada dalam katagori sedang, namun masih adanya itemitem yang memiliki nilai rendah dalam pernyataan "Saya senang menceritakan pengalaman menyenangkan kepada guru" mewakili aspek berbagi, "Saya menawarkan tempat duduk kepada teman yang tidak mendapatkan tempat duduk dikantin" mewakili aspek menolong, "Saya menyisihkan sebagian uang jajan saya untuk diberikan kepada teman yang kurang mampu." mewakili aspek berderma, "Saya mendahulukan tugas kelompok diantara banyak tugas demi kesuksesan 
bersama" mewakili aspek kerjasama, dan "Saya menyontek pada saat ujian" dalam hal sikap jujur, hal ini menandakan bahwa masih diperlukan program untuk meningkatkan perilaku prososial siswa.

\section{Perilaku prososial siswa berdasarkan aspek dan indikator}

Berikut adalah hasil pengkategorian dan presentase tingkat penyesuaian diri peserta didik dari aspek-aspek mengenai perilaku prososial siswa :

Tabel 1

Gambaran aspek perilaku prososial siswa

\begin{tabular}{|c|c|c|c|c|c|}
\hline Aspek & $\begin{array}{c}\text { Berbagi } \\
\text { (Sharing) }\end{array}$ & $\begin{array}{c}\text { Membantu } \\
\text { (Helping) }\end{array}$ & $\begin{array}{c}\text { Berdermawan } \\
\text { (Donating) }\end{array}$ & $\begin{array}{c}\text { Kerjasama } \\
\text { (Cooperating) }\end{array}$ & $\begin{array}{c}\text { Jujur } \\
\text { (Honesty) }\end{array}$ \\
\hline Skor & $9,5 \%$ & $32,1 \%$ & $16,7 \%$ & $20,7 \%$ & $21 \%$ \\
\hline
\end{tabular}

Gambaran perilaku prososial siswa lebih rinci dapat dilihat dari indikator perilaku prososial siswa yang digunakan sebagai acuan perilaku yang masuk dalam penilaian, adapun indikator perilaku prososial siswa dapat dilihat pada tabel berikut:

Tabel 2

Profil Indikator Perilaku prososial Siswa Kelas XI IPS SMA Negeri 1 Cilegon

\begin{tabular}{|c|c|c|c|c|}
\hline Aspek & Indikator & Rendah & Sedang & Tinggi \\
\hline \multirow[b]{2}{*}{$\begin{array}{c}\text { Berbagi } \\
\text { (Sharing) }\end{array}$} & $\begin{array}{l}\text { a. Siswa berbagi } \\
\text { perasaan kepada } \\
\text { orang lain dalam } \\
\text { kondisi apapun }\end{array}$ & $7 \%$ & $46 \%$ & $47 \%$ \\
\hline & $\begin{array}{l}\text { b. Siswa } \\
\text { memberikan } \\
\text { kesempatan } \\
\text { kepada orang lain } \\
\text { untuk } \\
\text { mencurahkan isi } \\
\text { hatinya }\end{array}$ & $5 \%$ & $68 \%$ & $27 \%$ \\
\hline
\end{tabular}




\begin{tabular}{|c|c|c|c|c|}
\hline \multirow{2}{*}{$\begin{array}{l}\text { Membantu } \\
\text { (Helping) }\end{array}$} & $\begin{array}{l}\text { a. Siswa } \\
\text { memberikan } \\
\text { dukungan moril } \\
\text { kepada orang } \\
\text { yang } \\
\text { membutuhkan. }\end{array}$ & $7 \%$ & $67 \%$ & $26 \%$ \\
\hline & $\begin{array}{l}\text { b. Siswa } \\
\text { memberikan } \\
\text { dukungan materil } \\
\text { kepada orang } \\
\text { yang } \\
\text { membutuhkan. }\end{array}$ & $13 \%$ & $65 \%$ & $22 \%$ \\
\hline \multirow[t]{2}{*}{$\begin{array}{l}\text { Berdermawan } \\
\text { (Donating) }\end{array}$} & $\begin{array}{l}\text { a. Siswa bersedia } \\
\text { memberikan } \\
\text { barang miliknya } \\
\text { kepada orang lain } \\
\text { yang } \\
\text { membutuhkan. }\end{array}$ & $8 \%$ & $75 \%$ & $17 \%$ \\
\hline & $\begin{array}{l}\text { b. Siswa berlaku } \\
\text { murah hati untuk } \\
\text { beramal. }\end{array}$ & $10 \%$ & $72 \%$ & $18 \%$ \\
\hline \multirow[t]{2}{*}{$\begin{array}{c}\text { Kerjasama } \\
\text { (Cooperating) }\end{array}$} & 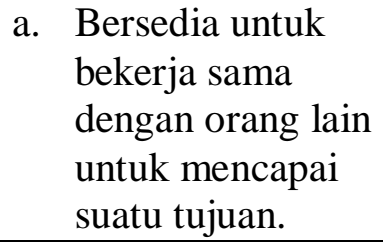 & $10 \%$ & $70 \%$ & $20 \%$ \\
\hline & 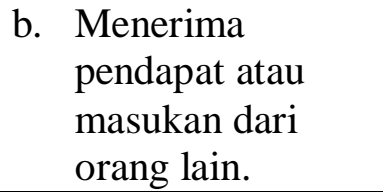 & $8 \%$ & $64 \%$ & $28 \%$ \\
\hline \multirow[t]{2}{*}{ Jujur (Honesty) } & $\begin{array}{l}\text { a. Siswa memiliki } \\
\text { sifat yang jujur } \\
\text { dalam hal apapun } \\
\text { agar dapat } \\
\text { dipercayai. }\end{array}$ & $10 \%$ & $60 \%$ & $30 \%$ \\
\hline & $\begin{array}{l}\text { b. Siswa mengakui } \\
\text { kesalahan yang } \\
\text { diperbuat }\end{array}$ & $16 \%$ & $63 \%$ & $21 \%$ \\
\hline
\end{tabular}

Berdasarkan tabel 2 dapat diketahui bahwa skor yang memiliki nilai terbesar di setiap indikator berada di kategori "sedang". Hal tersebut dapat menggambarkan bahwa siswa XI IPS SMA Negeri 1 kota Cilegon tahun ajaran 2019/2020 yang berada pada kategori sedang, memiliki sikap atau perilaku yang 
dapat mencerminkan karakteristik remaja yang paham akan perilaku prososial namun tidak secara keseluruhan karena masih adanya siswa yang memiliki perilaku prososial rendah dan peneliti merasa perilaku prososial tingkat sedang pun tidak cukup untuk mengoptimalkan perkembangan siswa. Oleh karena itu, perlu adanya peningkatan perilaku prososial siswa kelas XI SMA Negeri 1 Kota Cilegon tahun ajaran 2019/2020 agar seluruh siswa memiliki perilaku prososial yang tinggi.

\section{Aspek perilaku prososial siswa}

\section{a. Berbagi (Sharing)}

Hasil penelitian menunjukan dalam aspek berbagi berada dalam kategori "sedang". Berdasarkan hasil tabel 2 diperoleh 73\% atau 77 responden berada dalam kategori sedang, sedangkan untuk rendah berjumlah $7 \%$ atau 7 responden dan tinggi berjumlah $20 \%$ atau 21 responden. Meskipun hasil penelitian termasuk dalam kategori "sedang", namun dari hasil nilai butir angket menunjukan adanya masalah dalam aspek berbagi pada siswa XI IPS SMA Negeri 1 Cilegon. Hal ini dapat terlihat dari masih rendahnya nilai pada pernyataan "Saya senang menceritakan pengalaman menyenangkan kepada guru". Rendahnya nilai pada item ini dapat mempengaruhi emosi dalam psikologis siswa.

Peneliti berpendapat bahwa penting untuk meluapkan emosi, pengalaman, dan bercerita sebagai bentuk interaksi kepada orang lain. Hal ini dapat membantu memelihara kesehatan mental (psikologis) individu. Pendapat peneliti ini didukung oleh pernyataan Goleman (Al-baqi, 2015) yang menyatakan bahwa pada prinsipnya emosi dasar manusia meliputi takut, marah, sedih dan senang, malu, rasa bersalah, dan cemas sebagai emosi dasar manusia. Emosi tersebut penting karena sangat berpengaruh tidak hanya pada perilaku saat ini namun juga perilaku dimasa mendatang, terutama emosi negatif. Beragam pendapat juga menyatakan bahwa individu yang lebih sering bercerita tentang sesuatu yang membahagiakan atau tentang permasalahanya akan lebih sehat secara mental dibandingkan individu yang banyak menyimpan ceritanya sendiri. 
Linschoten (Al-baqi, 2015) menjelaskan bahwa perasaan manusia menurut modalitasnya terbagi menjadi tiga, yakni suasana hati, perasaan itu sendiri, dan emosi. Emosi merupakan bagian dari perasaan dalam arti luas. Emosi tampak karena rasa yang bergejolak sehingga yang bersangkutan mengalami perubahan dalam situasi tertentu mengenai perasaan, namun seluruh pribadi menanggapi situasi tersebut. Pada akhirnya, individu dapat menyesuaikan diri dengan lingkungannya dan menentukan respons yang sesuai terkait situasi yang dihadapi. Goleman (Al-baqi, 2015) menjelaskan bahwa pada prinsipnya emosi dasar manusia meliputi takut, marah, sedih dan senang. Lebih lanjut, Sutanto (Al-baqi, 2015) menambahkan malu, rasa bersalah, dan cemas sebagai emosi dasar manusia. Emosi tersebut penting karena sangat berpengaruh tidak hanya pada perilaku saat ini namun juga perilaku dimasa mendatang, terutama emosi negatif. Oleh karena itu, peneliti merasa penting bagi siswa untuk bisa berbagi dan mengekspresikan perasaan yang dihadapi demi kesehatan emosinya di masa mendatang.

\section{b. Membantu (Helping)}

Hasil penelitian menunjukan dalam aspek membantu berada dalam kategori "sedang". Berdasarkan hasil tabel 2 diperoleh $59 \%$ atau 62 responden berada dalam kategori sedang, sedangkan untuk rendah berjumlah $17 \%$ atau 18 responden dan tinggi berjumlah $24 \%$ atau 25 responden. Meskipun hasil penelitian termasuk dalam kategori "sedang", namun dari hasil nilai butir angket menunjukan adanya masalah dalam aspek membantu pada siswa XI IPS SMA Negeri 1 Cilegon. Hal ini dapat terlihat dari masih rendahnya nilai pada pernyataan "Saya menawarkan tempat duduk kepada teman yang tidak mendapatkan tempat duduk dikantin" dan "Saya menyapu kelas meskipun bukan jadwal saya membersihkan". Hal ini menandakan bahwa siswa masih enggan memberi bantuan-bantuan kecil kepada lingkungan dan orang sekitar. Selain itu, item pernyataan "Saya memberikan pulpen kepada teman" juga termasuk rendah, hal ini menandakan siswa belum mampu memberikan bantuan materil meskipun kecil kepada orang lain. Siswa juga dinilai kurang mampu 
menunjukan empati, hal ini terlihat dari rendahnya nilai pada item pernyataan "Ketika teman saya mengikuti olimpiade, saya datang mendukung dan menjadi suporter." Serta pada pernyataan "Saya menertawakan teman saya yang terjatuh.”.

Membantu secara harfiah menurut Kamus Besar Bahas Indonesia memiliki arti memberi sokongan atau dukungan dalam bentuk tenaga dan sebagainya supaya orang lain lebih kuat, kukuh, berhasil baik, ringan dan sebagainya. Perilaku membantu dapat dipengaruhi oleh berbagai faktor. Sarwono (Avivah, 2016) membagi faktor yang mempengaruhi seseorang dalam membantu orang lain menjadi dua sumber yaitu Situasional dan Internal. Faktor situasional merupakan faktor yang sumbernya berasal dari luar pilihan individu yang lebih cenderung pada kondisi korban, misalnya lingkungan sekitar, daya tarik korban, atribusi korban, model atau motivasi, tekanan waktu dan keterdesakan kebutuhan korban untuk dibantu. Sedangkan untuk faktor internal adalah faktor yang berasal dari kondisi penolong, misalnya suasana hati $(\operatorname{mood})$, sifat, jenis kelamin, tempat tinggal dan pola asuh.

\section{c. Berdermawan (Donating)}

Hasil penelitian menunjukan dalam aspek berdermawan berada dalam kategori "sedang”. Berdasarkan hasil tabel 2 diperoleh 64\% atau 67 responden berada dalam kategori sedang, sedangkan untuk rendah berjumlah $17 \%$ atau 18 responden dan tinggi berjumlah $20 \%$ atau 19 responden. Meskipun hasil penelitian termasuk dalam kategori "sedang", namun dari hasil nilai butir angket menunjukan adanya masalah dalam aspek berdermawan pada siswa XI IPS SMA Negeri 1 Cilegon. Hal ini dapat terlihat dari masih rendahnya nilai pada pernyataan "Saya menyisihkan sebagian uang jajan saya untuk diberikan kepada teman yang kurang mampu." rendahnya item ini dapat mempengaruhi sifat empati yang harusya ada dalam diri siswa.

Secara harfiah empati Empati adalah keadaan psikologis yang mendalam, seseorang menempatkan pikiran dan perasaan diri sendiri ke 
dalam pikiran dan perasaan orang lain yang dikenal maupun orang yang tidak dikenal (Farid \& Hasyim, 2012). Hadirnya perasaan empati dalam diri individu khususnya siswa yang berusia remaja dipaparkan Farid \& Hasyim (2012) berguna untuk membantu remaja mengembangkan potensi kebajikan,sehingga terwujud dalam kebisaan baik dalam hati,pikiran, perkataan, sikap, dan perbuatan,jika perasaan ini hilang dari diri seorang individu maka ia akan mengalami penurunan nilai-nilai sosial dan moral serta kurangnya kepedulian kepada orang lain.

\section{d. Kerjasama (Cooperating)}

Hasil penelitian menunjukan dalam aspek kerjasama berada dalam kategori "sedang". Berdasarkan hasil tabel 2 diperoleh $70 \%$ atau 74 responden berada dalam kategori sedang, sedangkan untuk rendah berjumlah 9\% atau 9 responden dan tinggi berjumlah $21 \%$ atau 22 responden. Meskipun hasil penelitian termasuk dalam kategori "sedang", namun dari hasil nilai butir angket menunjukan masih adanya masalah dalam aspek kerjasama pada siswa XI IPS SMA Negeri 1 Cilegon. Hal ini dapat terlihat dari masih rendahnya nilai pada pernyataan "Saya mendahulukan tugas kelompok diantara banyak tugas demi kesuksesan bersama". Peneliti merasa bahwa perilaku ini dapat memicu tumbuhnya sikap individualis di dalam diri siswa. Sikap individualis merupakan sikap yang menekankan peran dan kepentingan perorangan atau pribadi (Fisikawati et al). Individualisme berpandangan, bahwa pribadi, perorangan memiliki kedudukan utama dan kepentingan pribadi, kepentingan perorangan merupakan urusan yang paling tinggi. Individualisme menjebak orang untuk memiliki cara hidup yang "semau gue" yang mendewakan kepentingan pribadi dan mengabaikan kepentingan bersama. Sikap ini dapat memicu individu berperilaku mementingkan keuntungan untuk diri sendiri dengan mengandalkan cara apapun termasuk dengan cara membuat orang lain kesulitan.

Metode mengerjakan tugas dengan cara berkelompok sejatinya dibuat untuk memupuk rasa solidaritas dan menjalin interaksi untuk saling 
membantu, berpendapat dan membentuk sikap gotong royong didalam diri individu. Namun pada kenyataanya, tugas kelompok seringkali hanya dikerjakan oleh beberapa anggota kelompok saja, bahkan ada yang mengerjakan tugas kelompok seorang diri dikarenakan anggota kelompok yang lain lebih mementingkan tugas dan kepentingan dirinya sendiri dibandingkan tugas bersama didalam kelompok. Peneliti menduga adapula siswa yang mengandalkan orang lain untuk mengerjakan tugas kelompoknya tanpa hadirnya dia sendiri berpartisipasi dalam kelompoknya. Jika sikap individualis ini dibiarkan tumbuh dan berkembang dalam diri siswa, maka akan memberikan dampak negatif pada diri siswa, seperti: kehilangan rasa solidaritas terhadap sesame, Egoisme yang tak terbatas, dan Kesulitan dalam bersosialisasi (Fisikawati et al, 2018 :191). Hal-hal tersebut akan menurunkan nilai-nilai positif didalam perilaku prososial pada diri siswa.

\section{e. Jujur (Honesty)}

Hasil penelitian menunjukan dalam aspek jujur berada dalam kategori "sedang". Berdasarkan hasil tabel 2 diperoleh 63\% atau 66 responden berada dalam kategori sedang, sedangkan untuk rendah berjumlah $16 \%$ atau 17 responden dan tinggi berjumlah $21 \%$ atau 22 responden. Meskipun hasil penelitian termasuk dalam kategori "sedang", namun dari hasil nilai butir angket menunjukan masih adanya masalah dalam aspek jujur pada siswa XI IPS SMA Negeri 1 Cilegon. Hal ini dapat terlihat dari masih rendahnya nilai pada pernyataan "Saya menyontek pada saat ujian" juga pada pernyataan "Ketika ada razia di sekolah, saya memilih menyembunyikan hp di kantin". Hal ini menandakan bahwa perilaku prososial aspek jujur belum tumbuh dengan baik dalam diri siswa.

Sikap jujur merupakan sikap yang mengacu pada arti penuh kebenaran kesesuaian perkataan hati nurani, dapat dipercaya dalam segala hal, bertindak dengan adil, dan tulus. Nilai jujur juga disebut nilai yang tertanam dalam jiwa yang merupakan proses penyampaian informasi dan upaya untuk mendapatkan sesuatu dengan cara yang etis (Arlita, 2014). 
Sikap jujur tumbuh dalam diri seseorang dapat dipengaruhi berbagai faktor, menurut peneliti faktor yang mempengaruhi sikap jujur dalam diri seseorang antara lain pola asuh yang diterapkan oleh orang tua serta tekanan yang mungkin didapatkan dari lingkungan sekitar.

Sikap jujur merupakan sikap yang memerlukan pembiasaan untuk tumbuh didalam diri seseorang bahkan sejak dini. Jika seseorang sudah dibiasakan bersikap jujur sejak kecil maka tidak sulit untuk menerapkan sikap jujur pada dirinya dalam kehidupan sehari-hari, sebaliknya jika sesorang sudah terbiasa berbohong maka akan sulit merubah kebiasaan menjadi jujur. Sifat jujur penting dimiliki seseorang karena sifat jujur dapat membuat kita mempercayai kemampuan diri sendiri dan membuat orang lain juga dapat mempercayai apa yang kita katakan maupun yang kita lakukan, hal ini berlaku sebaliknya apabila kita bersikap tidak jujur maka kita tidak akan bisa mempercayai diri sendiri lalu oranglain pun tidak akan percaya kepada kita.

Mencontek merupakan salahsatu sikap tidak jujur yang biasa terjadi di wilayah sekolah, sikap ini merupakan salah satu bukti gagalnya siswa dalam menerapkan perilaku prososial. Dimasa yang akan datang, kebiasaan mencontek dapat menimbukan ketidakmandirian pada diri siswa. Berbagai sumber memberitakan bahwa mencontek merupakan budaya tidak jujur yang dapat membentuk karakter kriminal seperti koruptor, penipu, dan lain sebagainya.

\section{Rancangan Program Bimbingan Pribadi Sosial untuk meningkatkan Perilaku Prososial Siswa XI IPS SMA Negeri 1}

\section{Cilegon}

Berdasarkan hasil penelitian ini dapat dibuat program-program yang berdasar pada aspek pribadi sosial yang dibuat dalam bentuk program pecegahan atau preventif seperti program informasi dan penguatan untuk meningkatkan perilaku prososial siswa seperti bimbingan kelompok, bimbingan klasikal, karyawisata, serta diskusi terbuka. Program bersifat kuratif atau penanggulangan masalah perilakku prososial yang masih 
rendah dibeberapa aspek juga dapat disusun dalam bentuk layanan konseling kelompok dan konseling individual namun tidak menutup kemungkinan pula untuk dibuat program bimbingan klasikal.

\section{Kesimpulan}

Hasil penelitian menunjukan semua aspek yang dinilai dari perilaku prososial yaitu berbagi, menolong,berderma,kerjasama dan jujur pada subjek penelitian yaitu siswa kelas XI IPS 1-4 SMA Negeri 1 Kota Ciegon Berada pada kategori sedang yaitu pada nilai 63\% dari keseluruhan penilaian. Namun, masih adanya perilaku yang kurang menunjukan aspek prososial masih harus diberi perhatian dan dibuatkan program khusus untuk memperbaiki kekurangan yang ada dan menigkatkan perilaku prorosial pada siswa SMA Negeri 1 Kota Cilegon khususnya untuk kelas XI IPS 1-4.

\section{Daftar Pustaka}

Amseke, F.V., \& M.P. Panis. (2020). Peran Perkembangan Moral Terhadap Perliaku Prososial Remaja. Jurnal Psikologi Universitas Muhammadiyah Lampung (PSYCHE) 2(2): 103-116.

Al-Baqi, S. (2015). Ekspresi Emosi Marah. Buletin Psikologi Universitas Gadjah Mada 23(1): 22-30.

Arlita, A. (2014). Nilai Jujur Remaja Ditinjau dari Kualitas Hubungan Orang TuaAnak dan Transmisi Nilai. Skripsi. Fakultas Psikologi Universitas Muhammadiyah. Surakarta.

Farid, M., \& Hasyim, M.M. (2012). Cerita Bertema Moral dan Empati Remaja Awal. Jurnal Psikologi Universitas Darul 'Ulum 7(1): 501-508.

Fisikawati, A.R., Y. Anggraeni., I. Wardani., \& D. Nuari. (2018). Mengembangkan Sikap Religius untuk Mengurangi Individualisme pada Siswa di Zaman Global. Prosiding Seminar Nasional "Penguatan Pendidikan Karakter Pada Siswa Dalam Menghadapi Tantangan Global” 11 April 2018. Pascasarjana Universitas Negeri Semarang: 189-193.

Herdiyanto, Y.K., \& E. Megawati. 2016. Hubungan antara Perilaku Prososial dengan Psychological Well-Being pada Remaja. Jurnal Psikologi Udayana 3(1): 132-141. 
Isnandar, T.W. (2010). Hubungan antara Konsep Diri dengan Perilaku Prososial pada SMA 1 Purworejo. Skripsi. Fakultas Psikologi Universitas Muhammadiyah. Surakarta.

Lestari, D., \& Partini. (2015). Hubungan antara Penalaran Moral dengan Perilaku Prososial pada Remaja. Jurnal Indigenous 13(2): 41-46.

Prasetyo,M.D. (2017). Nomophobia dan Prososial Pada Mahasiswa. Skripsi. Fakultas Psikologi Universitas Muhammadiyah. Malang.

Rahajeng, U.W., \& Wigati, T.Y.A. (2018). Perilaku Prososial Sebagai Prediktor Status Teman Sebaya Pada Remaja. Jurnal Psikologi Teori dan Terapan 8(2): 124-132.

Solihah, F. (2013). Konsep Bimbingan Konseling (Bk) Sekolah Menengah Atas (SMA) Dalam Memberikan Keterampilan Manajemen Diri Dan Pencegahan Korupsi. Jurnal Bimbingan Konseling Islam. 4(2):239-262.

Tandi, A.D.I. (2019). Perilaku Prososial Siswa dan Implikasinya terhadap topiktopik Bimbingan Pribadi Sosial. Skripsi. Fakultas Pendidikan Bimbingan dan Konseling Universitas Sanata Dharma. Yogyakarta.

Yusuf, S. (2009). Program Bimbingan dan Konseling Di Sekolah. Bandung: Rizqi Press

Yusuf, S., \& Nurihsan, J. (2008). Landasan Bimbingan dan Konseling. PT. Remaja Rosdakarya. Bandung. 